Arhe XVII, 33/2020

UDK 165

DOI https://doi.org/10.19090/arhe.2020.33.123-143

Originalni naučni rad

Original Scientific Article

\author{
KONSTANTINOS G. PAPAGEORGIOU ${ }^{1}$ \\ University of Athens, Department of Philosophy, Greece \\ DEMETRIOS E. LEKKAS ${ }^{2}$ \\ Hellenic Open University, Studies in Greek Civilization, Greece
}

\title{
TOWARDS THE MODEL OF CONTRIBUTORY EXPERT GENERALISTS
}

\begin{abstract}
The study of expertise has focused on the concept of specialization and specialists, both from a sociological and a biological perspective. It has been taken for granted that expertise concerns only specialization; even an individual characterized as a "polymath" or homo universalis is considered to be an expert specialist in many fields. Can expert specialists in many fields exist today? This question is deceitful or irrelevant since it cannot accommodate the concept of individuals who are neither specialists nor "poly-specialists", but have knowledge of a different level: not analytic, but, rather, synthetic and abstract stemming out from general surveillance, not from specific experience. Here, a new type of expert is proposed: a contributory expert generalist. Their necessity stems from the methodology of epistemme proper. Their characteristics will be identified and discussed, some empirical examples will be given and their expert status is going to be discussed using various theoretical approaches on expertise, namely SEA, SEE and STS (Science of Exceptional Achievement, Study of Expertise and Experience, Science Technology and Society).
\end{abstract}

Keywords: contributory expertise, epistēmē, science, alienation

\section{INTRODUCTION}

Taking things for granted may turn out to be a dangerous habit, albeit a necessary and inherent predisposition of all animals. Apart from science itself, one of the things that we have taken for granted for too

\footnotetext{
${ }^{1}$ Author's e-mail address: cconstantinoss@gmail.com

${ }^{2}$ Author's e-mail address: ja-dim@hotmail.com
} 
long is the exclusive status of the expert specialists - also known as contributory experts (K. A. Ericsson, Krampe, and Tesch-Römer 1993). There are still other forms of expertise, i.e. interactional experts, experiential experts etc. (H. Collins and Evans 2007). All known forms of expertise have the same point of reference, the same measure: contributory expertise, empowered by specialization. Science, technology, art, education, all have been developed succumbing to the golden standard of specialization. Who can blame them? Even classical philosophers such as Plato celebrated the superiority of excellent individuals. But did we rush to assume that excellence and specialization are identified? Plato himself was a polymath and we know Socrates (as a figure in Plato's Apology) was critical about individuals who could be perceived as experts by today's standards in both arts and crafts. He admired their skilfulness, yes, but it was more important to him for them not to possess "the truth". Such truth cannot be anything other than general surveillance, the cornerstone of epistēme. Notably, surveillance (epoptei $\bar{a}$ ) is defined as the result of the process of assigning observation back to abstract archetypes or theory. Anything else would be counterdialectic or supernatural. I will support, general surveillance is exactly what we have forgotten today, along with epistēme.

In the legendary era of classical philosophers, when someone had a question, they did not seek the advice of a specialist, but of a generalist: a philosopher. Specialists were not even highly esteemed individuals; they were the workers. Have we forgotten to include expert generalists in our modern view about expertise, or is it just another outdated concept? We will attempt to show its difference from anything which has existed until now (in the modern era), as well as its necessity both in terms of social impact and of the method of epistēmē. Expert generalists are not just another type of experts, but a new paradigm absolutely necessary in order to save science from its own methodology.

The paper starts by describing the differences between the methods of science and epistēme. It is discussed how this dichotomy has paved the way for the prevalence of the expert specialist as a natural expression of the scientific method and how it has displaced expert generalists and epistēmē alike. Expert generalists are described and some 
examples are given. Then other implications are discussed especially related to political philosophy; Marx's idea of alienation from his 1844 Manuscripts is used. Finally, we discuss how compatible and incompatible specialists and generalists are, to conclude that their existence is complementary.

\section{SCIENCE VS. EPISTEMME}

Some things are too big to fail - or so we thought. The institution of science is not just among the biggest, the strongest and the richest ones; even though there have been voices heard criticising it, its political power is equally enormous and its supporters are zealots believing in it beyond any doubt (Latour and Woolgar 1986; H.M. Collins and Evans 2002; H. Collins and Evans 2007; Feyerabend 1993). Alas, even science is wrong.

The simplest explanation lies in its methodology. The experimental method should stimulate our intuitive understanding or help us choose among the various elements and singletons that have resulted after we have finished constructing theory. Instead, it is being used as a proving method. However, logical positivism collapsed in the '50's especially after Quine's classic paper on the two dogmas of empiricism though for the wrong reasons. Quine attacked the distinction between analytic and synthetic truths, on one hand, and reductionism, on the other hand (Quine 1951). The problem, however, is even more fundamental: theory and logical truth should have no a priori meaning, no worldcontent to begin with; they cannot possibly have any real-life meaning, they are completely abstract. On the other hand, science is destined to wish to have meaningful theories. Does "concrete", meaningful thought fit anywhere in our theory? Yes, reality and theoretics (if we borrow a term from the theory of music) do have meaning. ${ }^{3}$ I am not merely transposing the problem one level further; science does not have step number one (theory) at all, and this is the exact problem, the lack of

\footnotetext{
${ }^{3}$ This dichotomy (abstract theory vs concrete reality) is characteristic of both Marx's youth and Feuerbach. Althusser expressed this dichotomy as Generality I vs Generality III correspondingly.
} 
foundations. It is legitimate to use conventions for interpreting a theoretical system, but how can I consider (in the sciences) reality to be a convention of some sort? I cannot, it is a contradiction in terms!

Logic forbids us to assume the cause based on the effect (except when no 1-1 correspondence has been stated and established; this fallacy even has a name: affirming the consequent). Nobody seems to worry; instead, the experimental method is now the golden standard in science. The experimental method is not only used to verify theories; we have gone as far as using it to introduce theories by the back door using the myth of the "naïve recorder". This myth, or fallacy, is basically describing our tendency to avoid the responsibility of properly constructing theories by claiming that we merely record data; hypothesis non fingo, data colligō.

Statistics is a typical mathematical field; all of its theorems are, of course, proved (based on logic, not statistics). Statistics is not a proving method in mathematics, nor can it be used to prove anything in the strict sense; the only proving method in mathematics is logic (Papageorgiou and Lekkas 2020). Even if one used a prior theorem in statistics to prove a new one, this does not and cannot qualify any specific theorem as a general proving method - especially outside statistics (as is the case with theorems in all mathematical fields). However, logic is a general proving method. Logic is a priori, in the sense that it is set up even before the first word is written in the sciences, for example it is used in the logical setup of a scientific paper (arguments, i.e. premises leading to conclusions, logical inferences), not a posteriori, as is the case with statistics. Statistics per se may only be as good (i.e. credible) as the level of logical consistency and logical analysis used. Essentially, logical analysis per se is the method of episteme - notably within the two pairwise conjunct methods of analysis-synthesis and of abstractionstructure (Papageorgiou and Lekkas 2018). It only follows naturally that logic concerns, or should concern, all of scientific and academic writing, in any form and for any purpose, whereas statistics is of concern to a great deal of scientific papers, but not of all.

Despite occasional problems in regards to the quality of the statistical analysis used - or even the manipulation of results towards 
making them more appealing, or "significant" (Ioannidis 2005, 2012), statistical analysis is the golden standard of the contemporary scientific method. The problem has, therefore, already been identified. We have reinvented logical positivism as statistical positivism (we now use statistics, not logic) - only now we don't even make theories to verify them afterwards, they magically appear on their own. At least we are objective this way, right?

Objectivity is out of the question e.g. due to the Pythagorean shrewd standard reference to apatē, the fault of the senses. The very idea, the world may and can directly provide the answers we need had already been abandoned in classical antiquity - and this exact decision having cut our bonds with the past, enter the axiomatic method. The foundation of knowledge is theory, a system completely devoid of any content, any signified; theory, however, can and may be used as the archetypical structure by which the world, i.e. the meaningless save sensible phenomena are categorized based on our conscious and rigorous decision to match them to pre-defined criteria. The phenomena are meaningless by their own right. We categorize them and attach meaning to them based on our habits ( $c f$. the Humean discussion about causality). The issue is epistemological: what we observe is an entity, but is it an element or a singleton (unit-set)? This is not for the phenomenon to decide for itself but for us, based on our theoretical framework of choice. Even this slight difference is dramatic: is the table that I observe an element which has parts (e.g. a surface, four legs, nails), or a singleton which is a subset of other supersets (e.g. brown colour, hardness, flatness) $?^{4}$ Western scientists have forgotten, modus indicativus was a Roman insertion into Greek Grammar - or maybe a distortion of Greek grammar, for sure a breach of the terminological calque of a grammarian methodology and vocabulary. The Greeks had modus definitivus, so to speak. Wherever the Greeks saw a dead-end and decided that the best way to describe the

\footnotetext{
${ }^{4}$ These questions that are also crucial for developing a more consistent logical
} and set-theoretical system were asked (and answered in private) by D. E. Lekkas. 
world is to define $e^{5}$ it a priori, Latin scholars thought (maybe?) that if Roman Rule of Law was to be any good, the best way is to directly indicate things, i.e. point at them. Modus indicativus had, in that sense, more bang for the buck!

Then, there is an almost classic line of thought in neurosciences: the stimulus, e.g. photons (which have never been observed and cannot possibly be directly observed regardless every specialist's spontaneous reactions to the contrary), allegedly reach our lenses, get inverted, reach the retina, get transformed into chemical signals in the cones and rods, get converted back and forth from a chemical to an electrical signal millions or billions of times, get filtered, modified (to become "relevant") and supplemented (to account for imperfections such as the blind spot) by every conceivable way and finally become a (personal) conscious experience that means completely different things to different people, each of them being completely incapable of knowing the personal conscious experience (qualia) of another person. In logic, this inescapable deadlock of intersubjectivity is resolved using the simplest, the most elegant and strong axiom: we define (not indicate!) when two people agree, then their agreement is as binding as if we had a way of knowing, what they have in their minds is identical in every relevant way:

$$
A=A
$$

Another line of thought is relevant in the observations and interpretations of the experiments being dependent on the pre-existing theory, a theme expressed in Althusser's three Generalities (Althusser 1990, 1969). Generalities I (abstract, theoretical, prior, defining) also have social and political connotations. Generalities III (concrete, posterior, defined) can never have an "independent life". As long as science is a powerful institution, among other things, some social and political connotations and implications are relevant to our discussion as well.

${ }^{5}$ Definitions: a set of propositions in meta-language describing an entity fully and exclusively. Since definitions are (preferably) set in dummy languages, there is no meaning in demanding definitions for the words included in definitions. 
Technology cannot bypass our fraudulent approach to the cosmos, in exactly the way a shaman cannot use any Holy Plant to become wiser, even though they can, and do see the subtle world with the help of such Plants - experienced shamans do not need the Plants to achieve trance states. Likewise, science is reduced to mere witchcraft - at least to the extent that it boasts about its supposed objectivity. We have to fully respect all shamanic traditions, even as knowledge systems. However, while shamans do know that they use witchcraft, scientists are led to believe that they do not practise witchcraft, even though they follow the exact same methodology as sorcerers (a celebrated path from effect to cause) because they spend billions of dollars to "prove" otherwise. In that sense, shamience, sorry, science is not remotely as ecological as shamanism is.

What are we left with if we exclude objectivity? Epistemen has objective, subjective and theoretical knowledge. Theoretical knowledge keeps its distance from the world and has no ambition whatsoever to be applicable or "provable" in the world. In science, theories are being verified by observing the world, and similarly, in magick, one observes the subtle world to derive their knowledge. To sum up, another analogy could be the following:

epistèmē vs science vs witchcraft

or

theory vs fraud of the senses vs fraud of the subtle-senses...

...or why science and witchcraft have almost an identity relationship (since both are based on the affirmation of the consequent to develop their theories). It is really tempting to start debating about theory, its value and its structure - a rich discussion that could easily take up the space of many papers. Thus, in the best interest of both parties, mine and the reader's, we shall continue this discussion elsewhere (Papageorgiou and Lekkas 2014, 2019, 2018, 2020; Papageorgiou 2016). Here I shall merely juxtapose the methodological differences between these two knowledge systems (epistème, science) and how they are related to the different types of expertise. Let us focus on epistēmē. 


\section{THE METHOD OF EPISTEMME AND EXPERTISE}

The classic foundation of epistēme is the axiomatic method. D. Lekkas has presented in Epistēmēs Metron Logos the taxonomy of the methods used in epistēme (in his understanding they should have been common ground - why aren't they?). They are thoroughly sustained by the pairwise couple; synthesis-analysis and abstraction-structure. The first pair is about elements and the second about sets or categories. Every theory constructed this way should be evaluated based on the four classic criteria used in the axiomatic method: consistency, fullness, productivity, elegance. Since these methods have been presented in the several papers that we have written for Epistemmēs Metron Logos, I will give a familiar practically expressed example here which will make it clearer what is meant by each method. Let us say that we have a house.

1. Analysis: we break down the house into its physical constituents: doors, windows, walls, bricks etc.

2. Synthesis: we take bricks, doors, windows etc. and we synthesize / compose / construct something, e.g. a house. Note: if we reconstruct the exact same house, the process is now called resynthesis (Gr. anasynthesis).

3. Abstraction: we include our house in (nested) supersets / categories: $\{\text { house }\}^{6} \subseteq\{$ urban house $\} \subseteq\{\text { residence }\}^{7} \subseteq$ protected space $\}^{8} \subseteq\{\text { space }\}^{9}$.

4. Structure: we deal with the properties of the specific house: sunny, comfortable, safe etc.

Can we do the same with experts?

1. Analysis: body parts of an expert, brain cells, tissue etc.

\footnotetext{
${ }^{6}$ In the sense of the singleton (unit set), a set with one element, one house.

${ }^{7}$ In the sense of places where people live.

${ }^{8}$ In the sense of places where all living beings take refuge or stay.

${ }^{9}$ The end of abstraction: mathematical space, a void signifier!
} 
2. Synthesis: putting together different material parts to make an expert.

Note: expert sprinters have more fast-twitch muscle fibres; so, in order to make a sprinter, one would need this kind of muscle tissue - or expert taxi-drivers have grown a larger hippocampal grey matter volume.

1. Abstraction: for example, experts are humans, mammals, animals etc. or experts are workers, middle-class etc.

2. Structure: expert in mathematics, expert in epistemology etc. (see also fig. 1 which is "nothing more" than the structural representation of expertise).

Note of caution: everything is relevant. We can analyse, synthesize, abstract or structure anything in infinite ways. There is no way to carry out any experiment a priori to help us decide which way; experiments will be made only afterwards, if and only if some of the processes described above are finished (all / some of them, depending on the occasion). Equally, there is no way to perform any experiment afterwards towards verifying any theory - we are not logical positivists! So, what do we do? We do it the way maths does it. When "sciences" and philosophy at some point became separate, maths was the only field which split in half, as if it were in the middle. Maths, apart from theory, is also philosophy and methodology. This methodology dictates: everything is relevant until we agree to a convention. Thereafter, we are fully and absolutely bound by our convention as if it were real. The selection process is always arbitrary; but, as soon as I select something, I cannot arbitrarily change the convention at a later stage (unless I decide to make a new convention and start all over!).

This dual-pair taxonomy is quite a revolutionary one with farreaching implications about how we make theories. The implications for expertise stem out of this symmetrical duality between the specific (or analytic) element and the general (or abstract) properties ${ }^{10}$. The study of specialized cases in epistemme is as important as the study of generalized -

\footnotetext{
${ }^{10}$ Properties are criteria of inclusion into sets.
} 
or higher-level - cases. The guidelines dictate, one should do both analysis and synthesis and never do analysis without synthesis.

This leads to a dual pair of contributory experts, i.e. experts who are able to substantially contribute to various fields. The first kind of individuals are expert specialists and the second type of individuals are expert generalists. Expert generalists are knowledgeable in many domains in the way, say, that an interactional expert would be. It is not about understanding the way "real" experts express themselves - or to be able to express ourselves in a way an expert panel could be deceived into thinking of us as a contributory expert specialist, in some sort of Turing test type of interview (cf. H. Collin's "walk the talk"). The paradigm presented here qualifies as a completely different standard which is not evaluated against the golden standard of the contributory expert specialist. Expert generalists are also "contributory" experts at a higher, more abstract level.

The key characteristic of generalists vs specialists is that they may be more competent in higher-order knowledge. For example, a physicist may be an expert in operating a particle accelerator, making measurements and refining the Standard Model. However, they may be unable to see, at a higher level, their methodology is problematic and against logic. For a physicist, the flying donkey effect (ad hoc confirmation of results) may seem way too simplistic and general to be accepted as a valid reason for the disqualification of their prestigious multi-billion based research. However, generalists are able to see exactly that: the broader picture. For generalists, flying donkeys may indeed beat CERN scientists' methodology, or generalists may themselves beat holy cows, such as the flawed definition of force in physics - as well as any definition in any domain which is based on effects. If only physicists had co-operated with expert generalists sooner!

I hypothesize here that exactly the way Latin scholars chose to re-name their principal "real-world" conjugational mood by dropping the nomenclature evoking the Greek grammatical mood "enclisis horistike (= definitive mood) and introducing a modus indicativus (= indicative mood) in its shoes, the same way expert generalists were "translated", or treated, as expert specialists. This, I take it, exactly reflects the way in 
which the original Greek grammatical mood's identification with its opposite had dire consequences for the dialectic method, reducing generalists to specialists had the same effects. It can be argued that the reasons are political in both cases. The Roman Rule of Law was better off with a more "realis" grammatical mood; in the same way, the institutional power of expert specialists was preserved by rejecting anyone who could have a different saying about someone else's expert field. Imagine NASA accepting critique about its space program from someone who just uses flutes and not billion-dollar equipment (flutes are the epistemological instrument of the theory of music in the same way as the epistemological instruments of geometry are the ruler and the compass). The situation is problematic for a host of reasons. Experts have acquired exclusive power in their fields, and no-one else is allowed to have any formal and serious saying. The situation is both ridiculous and dangerous. In some years we will have e.g. medical doctors who are specialized in the right ear of male middle-aged opera singers and nothing else. Together with this ultra-specialization comes less responsibility, thus the paradox: more power but less responsibility.

What about in 100 years? In 1000 years? In 10,000 years? Because the usual excuse is that we now know more, therefore one should specialize in narrower and narrower fields. Imagine what that would mean for the future when much more knowledge would have been accumulated! And the plausible end of the road is the great old calculusinspired joke about a specialist: someone who knows everything about nothing. The system is not viable by any standards. Contributory expert generalists are necessary, now.

Are there any practical examples of contributory expert generalists then? A composer knows a multitude of things about many different instruments, without being able to demonstrate world-class performance in any one of them. There might be exceptions, even Herbert von Karajan played the piano / harpsichord exceptionally. But then again, there is Furtwängler, Mitropoulos etc. If Karajan had not been a specialist in one instrument, that would not have made him any less important as a conductor! A contributory expert specialist mathematician should be able to tell where physics has gone wrong and the general direction that it 
should take, how to construct the theory of music properly, how to reform the Byzantine musical system, how to reconstitute the prosody of an ancient language or what to do with complex analysis and logic in mathematics. A generalist should be able to contribute in the methodology of all these fields without being a specialist in any of the said domains. Expert specialists in these domains (e.g. in logic) can understand the consequences of generalists' directions and do all the expert work that needs to be done, building the axiomatic system described. It is of no use being an expert in the complicated mathematics of the Ptolemaic system and then missing the whole point (that the earth is not the centre of the universe); moreover, it is very realistic to be unable to solve such complicated mathematical equations while being able to demonstrate that the earth is revolving around the sun (and I guess back then you would not be listened to if you were not proficient at solving equations, as was the case with Wegener and his formal education in geology when he forwarded the notion of the tectonic plates without world-class expert knowledge of geology and without any experimental data). Expertise is deeply authoritarian and political, hence best served by specialists. The generalist is less proficient than the specialist in a certain field but also absolutely indifferent for this supposed "insufficiency" (which they should be more than eager to admit!).

4 THE ALIENATION OF ACTIVITY, THE ACTIVITY OF ALIENATION ${ }^{11}$

The words "alienation" and "estrangement" (between workers and their products, or even more so between workers and the final product,) appear some 300 times in the 80 pages of Marx's Economic \& Philosophic Manuscripts of 1844. Of course, Marx refers to workers, but this is not his criterion (being a worker). The division of labour brings about alienation, and division of labour is what expert specialization is all about. Scientific knowledge and capitalist economy were something that Marx did not touch upon since in his time, they were disassociated (Goto

11 "If then the product of labour is alienation, production itself must be active alienation, the alienation of activity, the activity of alienation." (Marx 1844, 30) 
2013). My idea is to explore, in principle, a partial isomorphism between Marx's theory and the model of specialization in science.

The compartmentalization of scientific thought is, or should be, no more than a convention. Instead it has been taken as literal, i.e. the certainty has grown that scientific domains are actually separate and no "outsider" can interfere with the work of an expert. Since experts are so specialized, each expert is an island and there would hardly be any peers to judge them. Expert specialization is becoming even more narrow in the years to come.

Expert specialization in science, in contrast to the worker's labour, is making the expert more powerful. However, the differences end here. Expert specialization is not any better for the scientist, when it comes to estrangement from the higher-level scientific principles (let's even call them Generalities II, i.e., epistemology, ethics, methodology and theory of science etc.). Even this one very important difference is also detrimental, not just for the society that is led by absolute and unquestionable authorities, but for the scientists themselves who are slaves of their own power; in stark contrast to the worker's acquired passivity, scientists will go to any extent to preserve their status quo.

Marx, in his Manuscripts, describes the worker's declining mental clarity about their situation using the darkest colours: "So much does labour's realization appear as loss of realization that the worker loses realization to the point of starving to death" (p. 29). The damage done to science is directly proportional to the scientists' alienation with its general principles - especially their alienation with surveillance. Then, every scientific domain follows its own methodological path and the ensuing fragmentation weakens the cohesion of science's structure. We end up having many sciences, many logics, many theories, and since we also have been having Shamanism, religions, mysteries, ideologies etc., why choose anything over the others? Let's do whatever we want, combine them, or freely choose whatever perspective suits our needs better. Why astronomy and not astrology, why astrology and not astronomy, why not astronomy and astrology combined? Overspecialization without anything to counterbalance it will eventually lead to the weakening and the degeneration of science. 
If this is what the scientists are willing to support for the sake of keeping their power, or even to increase it, then the opposite of what Marx says about the consequences to the workers will apply to the scientists. I paraphrase Marx's remarks (p. 29) ${ }^{12}$ :

"For on this premise it is clear that the more the [scientist] spends himself, the [less] powerful becomes the alien world of [theories] which he creates over and against himself, the poorer he himself - his inner world - becomes, the less belongs to him as his own".

\section{TOWARDS A UNIFYING MODEL OF EXPERTISE}

Going through the various works in the relevant literature, especially the ones which explain how specific expertise is, one is inclined to wonder if the whole theoretical foundation of expertise is not just another case of data dictating theory (Hill and Schneider 2006, 658; Feltovich, Pretula, and Ericsson 2006, 46-60; Thorndike and Woodworth $1901^{13}$ ). Until now no theory of expertise has ever been developed by anyone, save well-structured notes on observations. A theory would not only define expertise, but it would explicate all its causalities, both necessary and telic, define (in principle) its various categories and analytic components and so on and so forth.

Accommodating generalists is possible, even in the current (pseudo-?) theoretical framework. It may easily be argued that the generalists' overview of the various fields is (for instance) at the level of methodology and not at the level of each field's rich knowledge substrate. The current scientific literature does not support the notion of an expert generalist as it is presented here. Even books that have generalists as their main subject, while considering their wide range of knowledge as a definite advantage, unavoidably identify them with polymaths; the latter,

\footnotetext{
12 Original text: "For on this premise it is clear that the more the worker spends himself, the more powerful becomes the alien world of objects which he creates over and against himself, the poorer he himself - his inner world - becomes, the less belongs to him as his own".

${ }^{13}$ Expertise specificity was studied as early as 1901 !
} 
having one or two main domains of expertise are trapped within the barren paradigm of science (Epstein 2019).

The scientific literature does not, at the same time, exclude the possibility of generalists to exist. Generalists are not merely "polymaths" in the sense that they know a bit of everything. They are experts in the outer, common layer of specialization fields. Indeed, one may view such outer layers as the connective tissue among the various sciences - after all, any separate discipline, from physics to psychology, should have at least one substantial common characteristic with the others if they are to be called "sciences" in a meaningful way. That common outer layer usually includes inference methods and methodology (which, in epistemēe, is not the experimental method, therefore it is much more unifying than the experimental method of science: some fields are poor in experimental means). I have tried to capture this idea in the following figure.

The figure is set up in the most intuitive way possible. The deeper we go, the more specialized knowledge / fields we find (note: the segmentation of knowledge into fields of study is merely a convention; here, for economy, we accept that knowledge $=$ fields). The deeper we go, the less the various fields interact or intersect. The deeper we go the less we can move horizontally.

Four kinds of experts are identified.

1. Contributory expert generalists: they have a broad scope but almost no depth.

2. Contributory expert specialists: they go deep but have almost no breadth.

Note: in order for any meaningful relationship to exist between generalists and specialists, their lines should cross at some point

3. Interactional expert: they have neither depth nor breadth. They know the jargon ("speak the way" as prof. Collins says). They can go as deep as the generalist goes or even deeper. They can also spread across domains (not visible in the figure).

4. Experiential expert: they do not know the field's jargon nor its methodology; they are at the level of contributory expert specialists but with no depth. 
Any other conceivable combination may be made: draw any kind of line on the graph and try to figure out to what type of expert or knower that would be. Or, alternatively, think of any kind of expert and try to figure out what kind of line represents them.

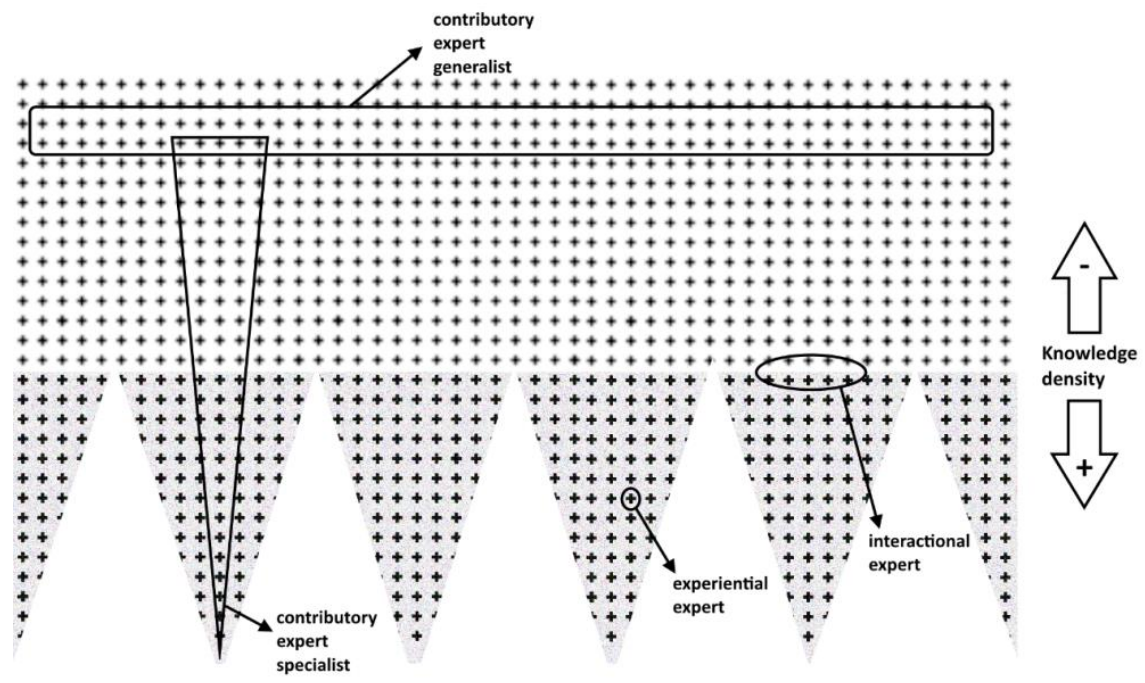

Expert Generalists in Practice

Interestingly, both motor- and cognitive-related domains are structured in a very favourable way for experts, but not for generalists. While technological advancements made it possible to have billion-dollar equipment with unprecedented possibilities, machines do not produce theory, but rather, record data (the naïve recorder myth of modern science). But it is impossible to only call data-collections "theories", no matter how bad we wanted it to be the case. Billion-dollar equipment has done exactly this: they obscure theoretical understanding by flaunting their stupefying size ( $c f$. enargeia: the feeling of profoundly understanding a simple and elegant truth). In classical antiquity, mathematicians refused to introduce any such technical complexity to their method; they insisted in doing geometry with nothing more complicated than a compass and a ruler! It was not a matter of lack of means; it was a matter of values and priorities. 
Another thing which has happened is the development of two epistemological diseases: mathematicism (an ailment mainly of expert mathematicians or people posing as such to present a theory using the most complicated and preferably incomprehensible ultra-sophisticated involved mathematical possible way to raise the level of sophistication, alienate the layman and ultimately muddy the waters) and quasi-mathematicity (an ailment mainly of non-mathematicians flirting with an involved and forbidding mathematical expression of anything in an effete mathematical language, making it appear more therefore convincing because of the awe and fear and admiration that it inspires). In both of these cases, if someone is not trained enough to understand (let alone express themselves) in an inaccessible mathematical jargon, they are automatically excluded from the particular/preferential category of "expert specialists".

So, if a generalist were to tell a physicist: "I do not know how to do advanced physics, I just see clearly that your definition of force is wrong", the physicist would probably respond with one of the following three:

1. You are not an expert, go away.

2. Look at the technology we have developed! ${ }^{14}$ Therefore, you must be wrong. Q.E.D.!

3. Look at the equations of the standard model and trace the mistake (equations which physicists themselves cannot fully understand, have borrowed from mathematics, but at the same time won't listen to what mathematicians have to say about them since they work in practice!).

Expert specialists are as important as expert generalists. If analysis is as important as synthesis, having only experts in analysis makes no sense; it is equally as important to have experts in having the overview of science, otherwise, and especially with the future trends in further segmenting science

\footnotetext{
${ }^{14}$ Contrary to common belief - even among scientists themselves -, technology has only little to do with science (cf. Taleb 2012). Even if it were relevant, it is a logical fault to just simply point to an effect in order to "spontaneously" or "automatically" support a theory or indicate or establish a cause: $[\mathrm{A} \Rightarrow \mathrm{B}] \neg \Leftrightarrow$ $[\mathrm{B} \Rightarrow \mathrm{A}] A \rightarrow B \oplus B \rightarrow A$
} 
into sub-domains, we are at risk of having an even more incoherent fragmentary body of science.

All in all, contributory expert generalists i. base their knowledge on surveillance, not on experience, ii. have an internally interdisciplinary approach to knowledge (one person, per se, combines the knowledge of different domains vs. a "team of experts") iii. due to (i) and (ii) they are able to bridge the gap between "is" and "ought to be" - expert specialists can't. Especially in relation to the latter, it is irresponsible how scientists nowadays dictate the social measures to be taken for the COVID 19 pandemic without any consideration for the Humean guillotine that separates "is" (scientific data) from "ought to be" (laws). One reason for the social unrest after continuous lockdowns may be traced exactly in this trend. Of course, the existence of expert generalists is more a wishful thinking than a practical reality; in that case, bridging the gap between scientists (expert specialists) and politicians is the work of philosophers (whom nobody even considers).

\section{CONCLUSION}

The paradigm of the contributory expert generalist is destined to bring about multiple paradigm shifts, starting with the fields dealing with expertise and then on to other fields, such as physics and mathematics, which are expected to see considerable changes in their core beliefs and conventions.

I was asked by the late K. A. Ericsson if this line of research will improve things that matter, such as daily medical practice. This question could only come from a scientific mindset, that is, a mindset which is obsessed with results. But we must pause for even a brief moment and contemplate on why we, as a society, have chosen science over witchcraft or say oracles as our official source of information for political decisions and for the allocation of people's money (taxes). Then we must understand the reasons why epistème has been transformed into science. Was it a conscious choice? An accident? Was it for the better or for the worse? We have repeatedly argued that epistēmē has degenerated into science - at least partly. It makes no sense then to accept science but refuse to accept epistemme (without any sound reason); in episteme $\bar{e}$, the concept of a contributory expert 
specialist is as important as one of a contributory expert generalist. Trying to convince anyone about the importance of generalists based on results, is doing what we fight against: judging based on the results. In episteme $\bar{e}$ there are three kinds of causes; necessary, telic and poetic. The necessary cause is what is the cause in principle; telic cause merely reveals eventuality or purpose, i.e. what could be or would be. As for poetic cause, it is about the agent or the subject: who acted how and did what and who said what. So, what is that "result" which ruthlessly judges everything when the effect is not even the telic cause? Scientists appear compulsive in insisting on describing and evaluating things based on something belonging neither to epistēme nor to science. Should we not be alarmed? When? Where?

\section{REFERENCES}

Althusser, Louis. 1969. "On the Materialist Dialectic." In For Marx, 2005th ed., 161-218. London and New York: Verso.

— 1990. "On Theoretical Work: Difficulties and Resources." In Philosophy and the Spontaneous Philosophy of the Scientists \& Other Essays, edited by G. Elliot, 43-68. London and New York: Verso.

Collins, H., and R Evans. 2007. Rethinking Expertise. The University of Chicago Press.

Collins, H. M., and Robert Evans. 2002. "The Third Wave of Science Studies: Studies of Expertise and Experience." Social Studies of Science 32/2(April 2 (2): 235-96.

Epstein, David. 2019. Range: How Generalists Triumph in a Specialized World. Penguin.

Ericsson, K. Anders, R. T. Krampe, and C. Tesch-Römer. 1993. "The Role of Deliberate Practice in the Acquisition of Expert Performance." Psychological Review 100 (3): 363-406. http://doi.apa.org/psycinfo/ 199340718-001.

Feltovich, Paul J., Michael J. Pretula, and K. Anders Ericsson. 2006. "Studies of Expertise from Psychological Perspectives." In The Cambridge Handbook of Expertise and Expert Performance, edited by K. A. Ericsson, Neil Charness, Paul J. Feltovich, and Robert R. Hoffman, 41-68. Cambridge University Press.

Feyerabend, Paul. 1993. Against Method. Verso.

Goto, Kunio. 2013. "STS and Marxist Study: Where Are We Standing Now?" Social $\begin{array}{lllll}\text { Epistemology } 27 & \text { (2): } 125-29 . & \text { https://doi.org/10.1080/ }\end{array}$ 
02691728.2013 .793755$.

Hill, M. Nicole, and Walter Schneider. 2006. "Brain Changes in the Development of Expertise: Neuroanatomical and Neurophysiological Evidence about SkillBased Adaptations." In The Cambridge Handbook of Expertise and Expert Performance, edited by K. A. Ericsson, Neil Charness, Paul J. Feltovich, and Robert R. Hoffman, 653-82. Cambridge University Press.

Ioannidis, John P. A. 2005. "Why Most Published Research Findings Are False." PLoS Medicine 2 (8): e124. https://doi.org/10.1371/journal.pmed. 0020124. —. 2012. "Why Science Is Not Necessarily Self-Correcting." Perspectives on Psychological Science 7 (6): 645-54. https://doi.org/10.1177/ 1745691612464056.

Latour, Bruno, and Steve Woolgar. 1986. Laboratory Life: The Construction of Scientific Facts. Princeton University Press. https://books.google.com/ books?id=vJ-JueUwptEC\&pgis=1.

Marx, Karl. 1844. "Economic \& Philosophic Manuscripts of 1844." marxists.org. https://www.marxists.org/archive/marx/works/download/pdf/EconomicPhilosophic-Manuscripts-1844.pdf.

Papageorgiou, Konstantinos G. 2016. "An Anthropologist, Wild Scientists, Flying Donkeys and Other Animals (GR.)." Aetion, no. 4: 131-33.

Papageorgiou, Konstantinos G., and Demetrios Lekkas. 2014. "Epistēmē and (vs) Scientia." In Philosophy, Natural Sciences, Bioethics, 1-15. Athens. http://deeaef.gr/wp-content/uploads/2016/04/Papageorgiou-Lekkas-fulltext.pdf.

2018. "On the Methodology of the Analytic Method: Historical Account, Epistemological Suggestions, Stages." Epistēmēs Metron Logos, no. 1.

— 2019. "The Predicate Fabric of Abstraction: The Hard Test of Logical Inversion.” Epistēmēs Metron Logos, no. 2. https://doi.org/ 10.12681/eml.20573.

—. 2020. "Verification in Theory and in the Sciences." Epistēmēs Metron Logos, no. 3 (January): 25. https://doi.org/10.12681/eml.22106.

Quine, W. V. 1951. "Main Trends in Recent Philosophy: Two Dogmas of Empiricism." Philosophical Review 60 (1): 20-43.

Taleb, Nassim Nicholas. 2012. Antifragile: Things That Gain from Disorder. Vol. 27. Random House Publishing Group. https://books.google.com/ books?id=5fqbz_qGi0AC\&pgis=1.

Thorndike, L. E., and S. R. Woodworth. 1901. "The Influence of Improvement in One Mental Function upon the Efficiency of Other Functions." Psychological Review, no. 8: 247-61. http://psychclassics.yorku.ca/ Thorndike/Transfer/transfer1.htm. 


\author{
KONSTANTINOS G. PAPAGEORGIU \\ Univerzitet u Atini, Odsek za filozofiju, Grčka \\ DIMITRIOS E. LEKAS
}

Helenski otvoreni univerzitet, Studije grčke civilizacije, Grčka

\title{
KA MODELU DOPRINOSEĆIH STRUČNJAKA- GENERALISTA
}

\begin{abstract}
Sažetak: Proučavanje stručnosti fokusiralo se na pojam specijalizacije i specijalista - kako iz sociološke, tako i iz biološke perspektive. Uzimalo se zdravo za gotovo da se stručnost tiče samo specijalizacije; čak i pojedinci koji su karakterisani kao „polimati” ili homo universalis-i smatrani su stručnjacimaspecijalistima u mnogim oblastima. Mogu li danas postojati stručnjaci koji bi bili specijalisti u brojnim oblastima? To je pitanje varljivo ili nevažno jer ne može prihvatiti pojam pojedinaca koji nisu ni specijalisti, niti ,polispecijalisti”, već raspolažu znanjem drugačijeg stupnja: ne analitičkim, nego radije sintetičkim i apstraktnim, koje proizlazi iz opšteg sagledavanja, a ne iz posebnog iskustva. Ovde se predlaže novi tip stručnjaka: doprinoseći stručnjaci-generalisti. Njihova nužnost potiče od metodologije prave epistēmē. Biće identifikovane njihove karakteristike i o tim karakteristikama će se raspravljati, biće dati pojedini empirijski primeri, a o njihovom ekspertskom statusu raspravljaće se korišćenjem različitih teorijskih pristupa stručnosti, naime nauke o izuzetnim postignućima (SEA), studije stručnosti i iskustva (SEE), kao i naučne tehnologije i društva (STS).
\end{abstract}

Ključne reči: doprinoseća stručnost, epistēmē, nauka, otuđenje

Primljeno: 25.2.2020.

Prihvaćeno: 6.5 .2020$. 